\title{
ZAKAT LEMBAGA KEUANGAN SYARIAH SEBAGAI BADAN HUKUM
}

\author{
Imam Mustofa \\ STAIN Jurai Siwo Metro \\ e-mail: imammustofa472@yahoo.co.id
}

\section{ABSTRACT}

Normatively zakat of asset that must be payed is 5 kinds, namely: cattle, agriculture, trade alms, gold and silver, and rikaz. Some contemporary scholars like Yusuf Qaradawi, Ali al-Salus, Muhyiddin al-Ashfar perform ijtihad of Islamic law related to the development of various assets must be payed a zakat. Yusuf Qaradawi, for example, based on the results of his ijtihad, considering the realities of modern economic activity, he recommended nine kinds of asset that must be payed zakat. He added 4 assets, namely: honey and animal production, minerals and marine products, investment in plant, buildings, zakat profession, stocks and bonds. Furthermore, contemporary scholars also discussed the obligation of zakat institution or legal entity. Based on the ijtihad, Islamic Financial Institutions is obligated to pay zakat because it is a subject of law and as well as a profitable business entity.

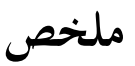

زكاةالأصول التييجب دفعها أصلا هي ه أنواع وهي :الماشية والزراعة وصدقات التجارة والذهب والفضة وركاز. بعض العلماء المعاصرين مثل يوسف القرضاوي، علي السالوس، وميي الدين الأصفر اجتهدوا في الشريعة الإسلامية المتعلقة بتطوير الأصول المختلفة التي تجب زكاتها. يوسف القرضاوي، على سبيل المثال، استنادا إلى نتائج اجتهاده، والنظر في واقع النشاط الاقتصادي الحديث، أوصى تسعة أنواع من الأصول التي تجب زكاةًا. وأضاف ع أصول، وهي :العسل والإنتاج الحيواني، والمعادن والمنتجات البحرية، والاستثمار في المصانع والمباني، وزكاة المهنة والأسهم والسندات. وعلاوة على ذلك، ناقش العلماء المعاصرين أيضا التزام زكاة المؤسسة اوالكيان 


\section{القانوني. وبناء على الاجتهاد، تلتزم المؤسسات المالية الإسلامية لدفع الزكاة لأها خاضعة للقانون وكذلك كيان بتحاري مربح.}

Keywords: zakat LKS, badan hukum, ijtihad, zakat profesi.

\section{A. Pendahuluan}

Zakat ${ }^{1}$ merupakan salah satu kewajiban muslim yang tidak hanya sebagai ibadah mahdhah pertanda hubungan harmonis secara vertikal dengan Allah SWT, tetapi juga sebagai kewajiban yang bersifat horizontal sesama muslim dan sesama manusia. Artinya zakat juga merupakan salah satu bentuk filantropi dalam Islam.

Secara normatif harta yang harus dizakati ada 5 macam, yaitu zakat binatang ternak, zakat pertanian, zakat perdangan, zakat emas dan perak, dan harta rikaz. Seiring dengan perkembangan zaman dan aktifitas ekonomi serta berbagai kegiatan yang profitable, ulama kontemporer seperti Yusuf Qardhawi, Ali alSalus, Muhyiddin al-Ashfar melakukan ijtihad untuk pengembangan hukum Islam terkait macam-macam harta dan asset yang wajib dizakati. Yusuf Qarad-

1 Zakat secara garis besar ada dua macam, yaitu zakat fitrah dan zakat mal. Zakat fitrah yaitu zakat atas diri seorang muslim, baik mukallaf maupun tidak. Kedua zakat maal, yaitu zakat atas harta yang dimiliki oleh seorang mukallaf. Al-Quran dan al-Sunnah tidak selalu menggunakan kata zakat untuk menunjukkan terma harta yang harus dikeluarkan seseorang sebagai tanggung jawabnya sebagai seorang muslim. Al-Quran terkadang menggunakan terma shadaqah, seperti dalam surat al-Taubah ayat 60 dan ayat 103. Sementara terma shadaqah yang digunakan oleh al-Sunnah misalnya dalam riwayat Imam Muslim, dari Ibnu Abbas:

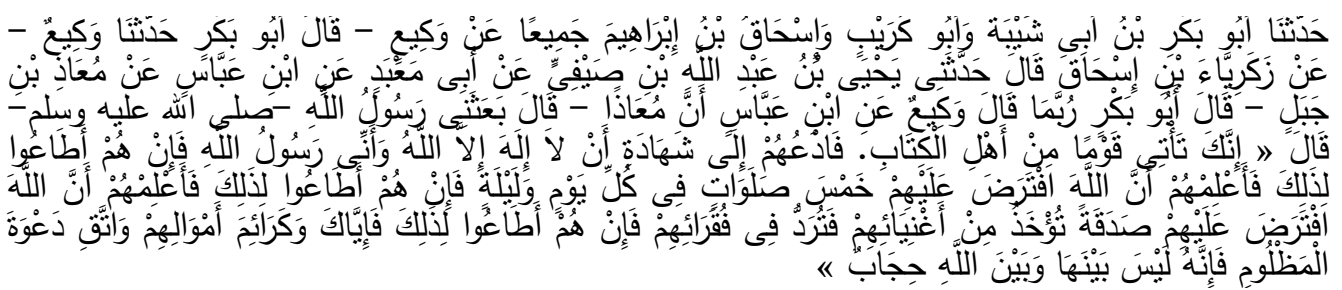

(Imam Muslim, Shohih Muslim, (Digital Library, Maktabah Syâmilah al-Ishdâr al-Tsân̂̂, 2005), I/37, hadis Nomor 130). 
hawi misalnya, berdasarkan hasil ijtihadnya dengan melihat realitas aktifitas ekonomi modern yang semakin variatif, berpendapat bahwa harta yang wajib dizakati ada Sembilan macam, yaitu: zakat binatang ternak, zakat emas dan perak/zakat uang, zakat kekayaan dagang, zakat pertanian, zakat madu, dan produksi hewani, zakat barang tambang dan hasil laut, zakat investasi pabrik, gedung, dan sebagainya, zakat pencarian dan profesi serta zakat saham dan obligasi. $^{2}$

Lebih jauh, ulama kontemporer juga mendiskusikan mengenai kewajiban zakat institusi atau badan hukum. Dalam hal ini Habib Ahmed menyatakan:

"There are many new items of income and wealth in contemporary times that determines financial status of individuals and institutions. But these latest items are not mentioned in the classical figh. Contemporary scholars have discussed same of these issues and argued that many assets and income sources of today need to be brought under the purview of zakah." ${ }^{3}$

Zakat badan hukum menjadi salah satu poin yang menjadi tema diskusi dan kajian di kalangan ulama kontemporer. Dalam hal ini Habib Ahmed menjelaskan:

"There are diverse opinions and views on the zakat ability of some other new items/entities. The new items of wealth and income that have been discussed by contemporary scholars include stocks and shares of companies, economic enterprises that are either wholly or partly owned by the government, mineral resources, including petroleum and income from the services sector business. The latter type of business are normally labor intensive no or very little capital and inventory investments (like travel agencies, law firms and real estate agents). Another contemporary economic reality is the existence of legal entities/person or other than natural person."

Salah satu ulama yang berpendapat tentang kewajiban zakat badan hukum atau lembaga adalah Yusuf al-Qaradhawi. Mengenai zakat perusahaan atau lembaga profit lainnya al-Qardhawi berpendapat bahwa tidak ada perbedaan pada zakat perusahaan yang bergerak pada perdagangan dan perusahaan bis-

2 Pembahasan lebih detail mengenai ketentuan zakat Sembilan macam harta yang wajib dizakati tersebut dibahas dalam kitab Fiqh Zakat Yusuf Qaradhawi hal. 167-501. Lebih lanjut baca Yusuf al-Qardhawi, Figh al-Zakah, (Beirut: Muassasah Risalah, 1973).

3 Habib Ahmed, Role of Zakah and Afqaf in Poverty Alleviation, (Jeddah: Islamic Develovment Bank, 2004), hal. 35.

4 Habib Ahmed, Role of Zakah and Awqaf in Poverty Alleviation, (Jeddah: Islamic Develovment Bank, 2004), hal. 36. 
nis selain perdagangan. Keduanya wajib mengeluarkan zakat. Dalam hal ini Qardhawi menyatakan:

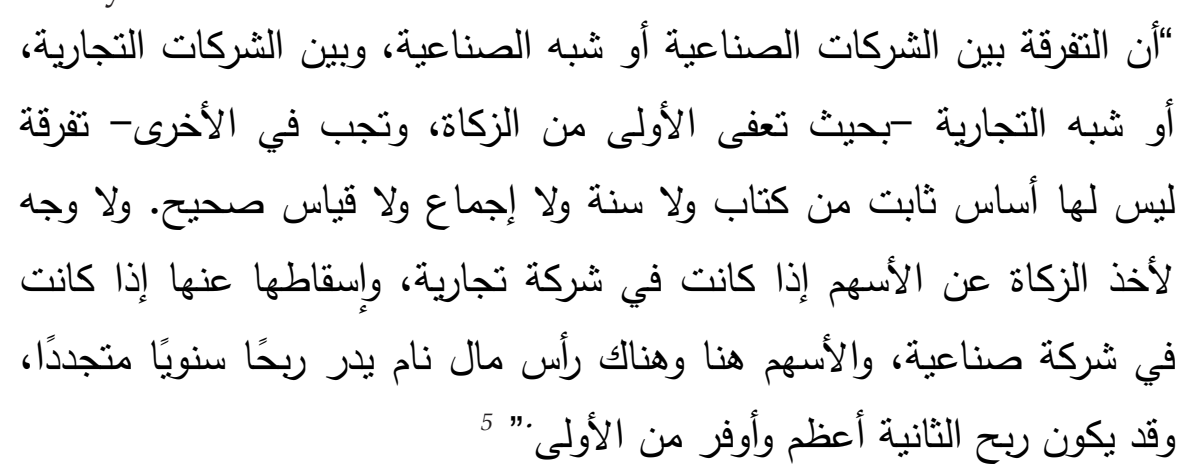

"Menurut Yusuf Qardhawi, membedakan perusahaan-perusahaan industri atau semi industri dengan perusahaan dagang atau semi dagang, di mana yang pertama dibebaskan dari zakat, sedangkan yang kedua tidak, ini merupakan pembedaan yang tidak berdasar pada al-Qur'an, hadis, ijma' dan qiyas yang benar. Menurut Qardhawi, hal tersebut dapat dianalogikan pada zakat pabrik dan gedung yang dianalogikan dengan zakat pertanian dan harus dikeluarkan zakatnya $10 \%$ atau $5 \%$ dari pendapatan bersih. Tidak ada landasan yang mengemukakan bahwa saham yang dikeluarkan dari perusahaan dagang diwajibkan zakat sedangkan yang dikeluarkan oleh perusahaan industri tidak wajib zakat, karena kedua perusahaan tersebut sama-sama merupakan modal yang tumbuh dan berkembang yang memberikan keuntungan tahunan yang terus mengalir, bahkan bisa jadi perusahaan industri memperoleh keuntungan yang lebih banyak atau lebih besar." 6

Jadi zakat badan hukum merupakan bagian dari kajian fikih kontemporer yang belum di atur bahkan belum disinggung dalam kajian fiqih klasik. Oleh karena itu regulasi zakat lembaga atau badan hukum ini berdasarkan ijtihad dan regulasi ayang dibuat oleh ulama kontemporer seperti Yusuf Qardhawi. Selain itu, zakat badan hukum atau perusahaan itu dilandaskan pada undangundang zakat yang berlaku pada suatu Negara.

5 Yusuf al-Qardhawi, Figh al-Zakah, (Digital Library, Maktabah Syâmilah al-Ishdâr al-Tsânî, 2005), I/455.

6 Diterjemahkan oleh Ririn Fauziyah dalam, Pemikiran Yusuf Qardhawi mengenai Zakat Saham dan Obligasi, dalam Jurisdictie, Jurnal Hukum dan Syariah, (Malang: Unit penelitian, penerbitan dan pengabdian Masyarakat (P3M) Fakultas Syariah Universitas Islam Negeri Maulana Malik Ibrahim ), Vol. 2, No. Juni 2011, hal. 166. 
Di Indonesia, zakat badan hukum atau perusahaan didasarkan pada undang-undang zakat dan Kompilasi Hukum Ekonomi Syariah (KHES). Berkaitan dengan zakat badan hukum atau perusahaan, undang-undang No. 38 Tahun 1999 tentang Pengelolaan Zakat pasal 11 ayat (2) menyebutkan:

"Harta yang dikenai zakat adalah: a) emas, perak dan uang; b) perdagangan dan perusahaan; c) hasil pertanian, hasil perkebunan dan hasil perikanan; d) hasil pertambangan; e) hasil peternakan; f) hasil pendapatan dan jasa; g) rikaz;"7

Sementara dalam pasal 4 ayat (2) Undang-undang No. 23 tahun 2011 tentang Pengelolaan Zakat disebutkan:

"Zakat mal sebagaimana dimaksud pada ayat (1) meliputi: a) emas, perak, dan logam mulia lainnya; b) uang dan surat berharga lainnya; c) perniagaan; d) pertanian, perkebunan, dan kehutanan; e) peternakan dan perikanan: f) pertambangan; g) perindustrian; h) pendapatan dan jasa; dan i) rikaz." 8

Selanjutnya pasal 3 undang-undang ini juga menyebutkan bahwa"Zakat mal sebagaimana dimaksud pada ayat (2) merupakan harta yang dimiliki oleh muzaki perseorangan atau badan usaha." ${ }^{\prime \prime}$

Sementara itu, dalam Kompilasi Hukum Ekonomi Syariah (KHES), secara jelas menyebutkan mengenai zakat badan hukum, pasal 675 ayat (1) dan (2) menyebutkan:

Yang dimaksud dengan:

1. Zakat adalah harta yang wajib disisihkan oleh seorang muslim atau lembaga yang dimiliki oleh muslim untuk diberikan kepada yang berhak menerimanya.

2. Muzaki adalah orang atau lembaga yang dimiliki oleh muslim yang berkewajiban menunaikan zakat.

Suatu badan hukum tidak akan lepas dari kontrol dan kekuasaan sesorang yang bertanggung jawab atas lembaga atau badan hukum tersebut. Artinya, akan selalu ada seseorang atau personal yang menjadi representasi lembaga tersebut. Berdasarkan pemikiran ini, maka kewajiban zakat untuk badan hu-

7 Undang-undang No. 38 Tahun 1999 tentang Pengelolaan Zakat pasal 11 ayat (2)

8 Undang-undang No. 23 tahun 2011 tentang Pengelolaan Zakat pasal 4 ayat (2)

9 Undang-undang No. 23 tahun 2011 tentang Pengelolaan Zakat pasal 4 ayat (3) 
kum atau sebuah lembaga dapat dimengerrti dan dipahami, karena pada dasarnya badan hukum adalah seubyek hukum sama halnya dengan seseorang yang mempunyai ahliyatul wujub dan ahliyatul ada'.

Tulisan ini akan mengupas lebih dalam tentang zakat lembaga keuangan syariah, mulai dari definisi, landasan normatif, syarat, nisab, ukuran dan haulnya. Hal ini penting untuk pertama, Sebagai upaya untuk membangun kesadaran berzakat di kalangan badan usaha, khususnya Lembaga Keuangan Syariah. Kedua, sebagai upaya sumbangan pemikiran bagi kriteria, prosedur dan syarat pelaksanaan zakat badan hukum, khususnya yang bergerak pada bidang bisnis atau dunia usaha. Kajian zakat badan hukum merupakan kajian kontemporer yang dipahami orang-orang tertentu, maka dengan tulisan dan kajian semacam ini akan dapat mennambah khazanah pemikiran dan memperluas pemahaman mengenai zakat lembaga atau badan hukum. Ketiga, sebagai usaha pengembangan keilmuan, khususnya terkait dengan fikih kontemporer dalam bidang mu'amalah. Fikih sebagai kajian ilmu produk manusia akan selalu berkembang seiring dengan perkembangan zaman dan aktifitas masyarakat. Terlebih fikih mu'amalah, ia diharapkan lebih cepat berkembang dengan merespon berbagai perkembangan kemajuan zaman agar para muslim pelaku bisnis cepat menemukan solusi bagi problem hukum terkait dengan kegiatan mu'amalah kontemporer.

\section{B. Badan Hukum: Definisi, Syarat dan Jenisnya \\ 1. Definisi badan hukum}

Istilah badan hukum (syakhshiah i'tibariyah hukmiyah) tidak disebutkan secara khusus dalam pandangan figh. Badan hukum dikatakan sebagai subjek hukum karena terdiri dari kumpulan orang-orang yang melakukan perbuatan hukum (tasharruf). Badan hukum merupakan hasil analogi dari keberadaan manusia dalam subjek hukum. Ketentuan menjadikan badan hukum sebagai subjek hukum, tidak boleh bertentangan dengan prisip-prinsip akad yang terdapat dalam Al-Quran dan sunnah. Keberadaan badan hukum terkaid dengan adanya 
penerapan akad wakalah dalam pembagian tugas (job description) darisuatu manajemen perusahaan. Dalam hal ini manusia bertindak sebagai wakil dari organ lembaga atau perusahaan tersebut. Meskipun atas nama badan hukum seseorang menjalankan amanah perusahaan, namun sebagai pertanggungjawaban vertikal tetap dikembalikan kepada amalan individu masing-masing. ${ }^{10}$

Badan Hukum adalah suatu perkumpulan orang-orang yang mengadakan kerja sama dan atas dasar ini merupakan suatu kesatuan yang telah memenuhi syarat-syarat yang ditentukan oleh hukum. Badan hukum merupakan pendukung hak yang tidak berjiwa (bukan manusia) dan merupakan gejala sosial yaitu suatu gejala yang riil, sesuatu yang dapat dicatat dalam pergaulan hukum, biarpun tidak berwujud manusia atau benda yang dibuat dari besi, batu dan sebagainya, tetapi yang terpenting bagi pergaulan hukum adalah karena badan hukum itu mempunyai kekayaan yang sama sekali terpisah dari kekayaan. ${ }^{11}$

Skema Pembagian Subjek Hukum ${ }^{12}$

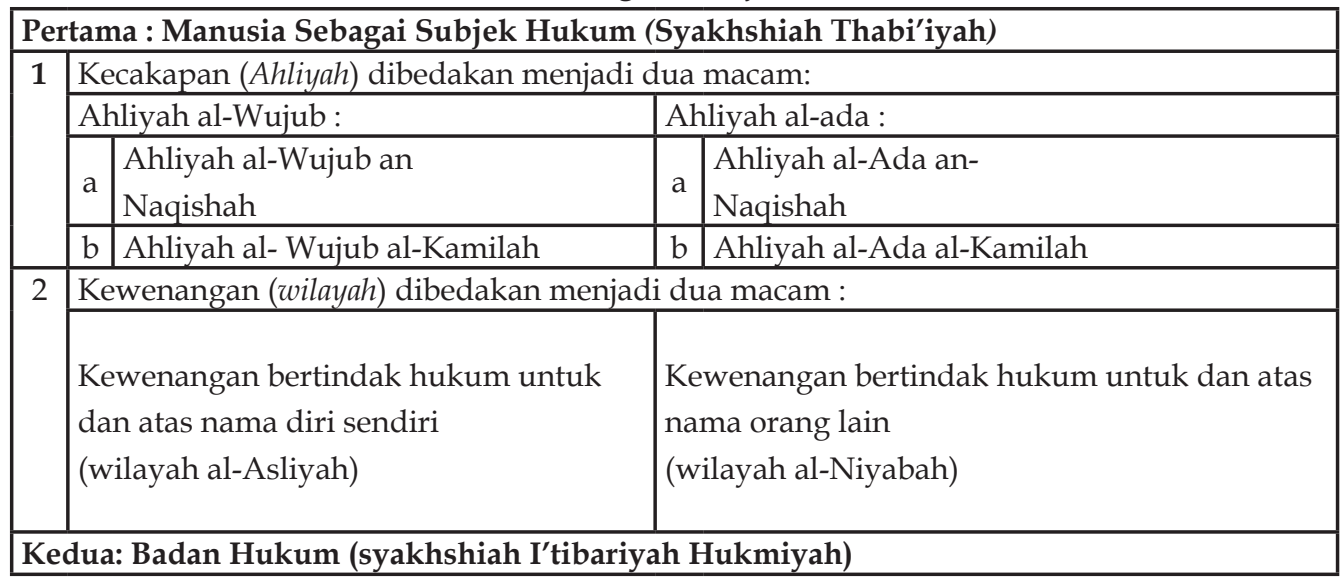

Syahrani sebagai dikutip oleh Bambang Purwoko membagi pengertian badan hukum dalam dua bagian sebagai berikut: pertama, badan hukum adalah suatu organisasi yang nyata, yang menjelma sungguh-sungguh dalam pergaulan hukum yang dapat membentuk kemauan sendiri dengan perantaraan alat alat yang ada seperti anggota sebagai pengurus dalam badan yang dimaksud; kedua,

\footnotetext{
10 Burhanudin S, Hukum Bisnis Syariah, (Yogyakarta: UII Press, 2011), hal. 7-8.

11 R. Soeroso, Pengantar Ilmu Hukum, (Jakarta: PT. Sinar Grafik, 1993), 238.

12 Burhanudin S, Hukum Bisnis..., hal. 8.
} 
badan hukum adalah suatu hak dan kewajiban para anggota bersama-sama dengan kekayaan badan hukum sebagai kekayaan bersama semua anggota. ${ }^{13}$

\section{Syarat-Syarat Badan Hukum}

Untuk keikut sertaannya dalam pergaulan hukum maka suatu badan hukum harus mempunyai syara-syarat yang telah ditentukan oleh hukum, yaitu:

1. Memiliki kekayaan yang terpisah dari kekayaan anggota-anggotanya.

2. Hak dan kewajiban badan hukum terpisah dari hak dan kewajiban para anggota-anggotanya. ${ }^{14}$

Berangkat dari pemaparan di atas, maka zakat badan hukum dapat didefinisikan sebagi zakat harta yang wajib dikeluarkan oleh badan hukum atau lembaga yang dimiliki oleh muslim untuk diberikan kepada yang berhak menerimanya atau mustahiq sesuai dengan syariat Islam dan hukum serta regulasi yang berlaku di suatu negara. Pada penelitian ini, badan hukum yang dimaksud adalah badan hukum yang profitable, bertujuan untuk mengembangkan harta dan mencari laba atau keuntungan, yaitu lembaga keuangan Syariah, seperti Baitul Mâl wa Tamwîl (BMT), koperasi syariah dan bank syariah.

\section{Jenis-Jenis Badan Hukum}

Menurut Wirjono Prodjodikoro sebagaimana dikutip oleh P.N.H. Simanjutak, badan hukum adalah suatu badan yang di samping manusia perorangan juga dianggap dapat bertindak dalam hukum dan yang mempunyai hak-hak, kewajiban-kewajiban dan perhubungan hukum terhadap orang lain atau badan lain. ${ }^{15}$ Ada beberapa jenis dan bentuk badan hukum yaitu:

13 Bambang Purwoko, Memahami Bentuk Badan Hukum Badan Penyelenggara Jaminan Sosial (BPJS) sebagaimana mestinya, makalah hasil penelitian, penelitian tentang kesesuaian bentuk bentuk badan hukum BPJS sebagaimana mestinya sesuai asas dan prinsip UU SJSN, tahun 2010, hal. 10.

14 R. Soeroso, Pengantar Ilmu Hukum, (Jakarta: PT. Sinar Grafik, 1993), hal. 238.

15 Lihat P.N.H. Simanjuntak, Pokok-Pokok Hukum Perdata Indonesia, (Jakarta: Djambatan, 2009), hal. 28-29. 


\begin{tabular}{|c|c|c|c|c|c|}
\hline No & $\begin{array}{c}\text { Jenis Badan } \\
\text { Hukum }\end{array}$ & $\begin{array}{c}\text { Bentuk Badan } \\
\text { Hukum }\end{array}$ & Definisi & $\begin{array}{c}\text { Tujuan dan } \\
\text { orientasi }\end{array}$ & Contoh \\
\hline \multirow[t]{3}{*}{1.} & \multirow[t]{3}{*}{$\begin{array}{l}\text { Badan } \mathrm{Hu}- \\
\text { kum Publik }\end{array}$} & $\begin{array}{l}\text { Badan Hukum } \\
\text { Publik yang } \\
\text { otonom }\end{array}$ & $\begin{array}{l}\text { institusi yang } \\
\text { memiliki } \\
\text { hak dan kewajiban } \\
\text { konstitusi serta } \\
\text { memiliki otoritas } \\
\text { pengawasan dan } \\
\text { regulasi secara } \\
\text { penuh, } \\
\end{array}$ & $\begin{array}{l}\text { Perlindungan } \\
\text { masyarakat baik } \\
\text { terhadap keru- } \\
\text { gian } \\
\text { ekonomi maupun } \\
\text { potensi gangguan } \\
\text { kamtibmas }\end{array}$ & $\begin{array}{l}\text { Kementerian2 } \\
\text { Bank Indone- } \\
\text { sia } \\
\text { Kejagung } \\
\text { Polri, BIN dan } \\
\text { BKPM }\end{array}$ \\
\hline & & $\begin{array}{l}\text { Badan Hukum } \\
\text { Publik semi- } \\
\text { otonom }\end{array}$ & $\begin{array}{l}\text { institusi indepen- } \\
\text { den yang mem- } \\
\text { punyai hak dan } \\
\text { kewajiban konsti- } \\
\text { tusional untuk } \\
\text { menye-lenggarakan } \\
\text { program-program } \\
\text { negara }\end{array}$ & $\begin{array}{l}\text { Pelayanan dan } \\
\text { pemberdayaan } \\
\text { masyarakat, }\end{array}$ & $\begin{array}{l}\text { PTN, BPS } \\
\text { BKKBN dan } \\
\text { sejenisnya }\end{array}$ \\
\hline & & $\begin{array}{l}\text { Badan Hukum } \\
\text { wali amanat }\end{array}$ & $\begin{array}{l}\text { badan independen } \\
\text { yang } \\
\text { dipercaya UU } \\
\text { untuk } \\
\text { menyelenggarakan } \\
\text { sistem jaminan } \\
\text { sosial dan kelola } \\
\text { dana amanah milik } \\
\text { peserta } \\
\end{array}$ & $\begin{array}{l}\text { Perlindungan } \\
\text { sosial terhadap } \\
\text { risiko-risiko sosial } \\
\text { ekonomi }\end{array}$ & \begin{tabular}{|l} 
DJSN \\
BPJS-BPJS
\end{tabular} \\
\hline \multirow[t]{4}{*}{2.} & \multirow[t]{4}{*}{$\begin{array}{l}\text { Badan } \mathrm{Hu}- \\
\text { kum Privat }\end{array}$} & $\begin{array}{l}\text { Perseroan } \\
\text { Terbatas }\end{array}$ & $\begin{array}{l}\text { Badan usaha yang } \\
\text { dibentuk dengan- } \\
\text { kum-pulan modal } \\
\text { baik milik pemerin- } \\
\text { tah maupun orang } \\
\text { per orang }\end{array}$ & Komersial / laba & $\begin{array}{l}\text { Persero negara } \\
\text { Persero swasta }\end{array}$ \\
\hline & & Koperasi & $\begin{array}{l}\text { kumpulan anggota } \\
\text { yang } \\
\text { dibentuk untuk } \\
\text { usaha } \\
\text { bersama yang } \\
\text { dibiayai } \\
\text { dari iuran anggota } \\
\end{array}$ & $\begin{array}{l}\text { Memperoleh sisa } \\
\text { hasi usaha untuk } \\
\text { kesejahteraan } \\
\text { anggota }\end{array}$ & $\begin{array}{l}\text { Koperasi2 } \\
\text { konsumsi dan } \\
\text { simpan pinjam }\end{array}$ \\
\hline & & Yayasan & $\begin{array}{l}\text { kumpulan orang } \\
\text { per orang yang } \\
\text { dibentuk untuk } \\
\text { misi sosial dan } \\
\text { kemanusiaan }\end{array}$ & $\begin{array}{l}\text { Fungsi kontrol } \\
\text { sosial }\end{array}$ & LSM \\
\hline & & Perorangan & $\begin{array}{l}\text { seseorang yang me- } \\
\text { nawarkan jasa kar- } \\
\text { ena kompetensinya }\end{array}$ & Bisnis dan hal lain & $\begin{array}{l}\text { Dokter praktek } \\
\text { dan pengacara }\end{array}$ \\
\hline
\end{tabular}

Sumber: Bambang Purwoko DJSN (Dewan Jaminan Sosial Nasional) ${ }^{16}$

${ }^{16}$ Bambang Purwoko, Memahami ..., hal. 12. 


\section{Badan hukum sebagai subyek hukum}

Pengertian subjek hukum berarti perbuatan manusia yang dituntut oleh Allah berdasarkan ketentuan hukum syara. Perbuatan yang dibebani hukum dalam ushul fiqh dikenal dengan istilah mukalaf. Subjek hukum terdiri dari dua macam yaitu manusia sebagai subjek hukum dan badan hukum, dalam rukun akad, kedua subjek hukum tersebut berkedudukan sebagai aqidain. Namun agar aqidain dapat mengadakan bisnis secara sah, maka harus memenuhi syarat kecakapan (ahliyah) dan kewenangan (wilayah) bertindak di hadapan hukum. ${ }^{17}$

Menurut teori tradisional, subyek hukum adalah orang yang merupakan subyek dari suatu kewajiban hukum atau suatu hak. Jika "hak" (Berechtigung) dipahami bukan semata sebagai hak refleks, melainkan wewenang hukum untuk mendesak (melalui gugatan hukum) dipenuhinya gugatan hukum, yakni wewenang hukum untuk berpartisipasi dalam penciptaan keputusan pengadilan yang membentuk sebuah norma individual yang memerintahkan eksekusi sanksi sebagai reaksi terhadap tidak dipatuhinyasuatu kewajiban; dan jika seseorang mempertimbangkan bahwa subyek dari wewenang hukum untuk menciptakan atau menerapkan norma hukum sama sekali tidak selalu disebut sebagai hukum, maka akan lebih mudah untuk membatasi konsep "subyek hukum" pada subyek kewajiban hukum dan untuk membedakan antara konsep "subyek kewajiban hukum" dari konsep" subyek wewenang hukum". ${ }^{18}$

Kompilasi Hukum Ekonomi Syariah pasal 1 ayat (2) menyebutkan bahwa: "Subyek hukum adalah orang perseorangan, persekutuan, atau badan usaha yang berbadan hukum atau tidak berbadan hukum yang memiliki kecakapan hukum untuk mendukung hak dan kewajiban."

Secara garis besar, ada dua macam subyek hukum, pertama, Natuurlijk person, adalah mens person yang disebut orang atau manusia. Kedua, recht person, adalah yang berbentuk badan hukum yang dapat dibagi dalam: (1) Publiek Recht-person, yang sifatnya ada unsur kepentingan umum, seperti negara; (2) Privat Recht-person/ Badan hukum privat, yang mempunyai sifat/adanya usnur kepentingan individual. ${ }^{19}$

17 Burhanudin S, Hukum Bisnis.., hal. 3.

18 Hans Kelsen, Teori Hukum Murni, (Bandung: Nusa Media, 2011), 190.

19 R. Soeroso, Pengantar Ilmu ..., hal. 228. 
Berkaitan badan hukum sebagai subyek hukum, setidaknya ada empat teori mengenai keberadaan badan hukum sebagai subyek hukum:

a. Teori fiksi (F.C. von Savigny, C.W. Opzoomer dan Houwing).

Menurut teori ini badan hukum dianggap buatan negara, sebenarnya badan hukum itu tidak ada, hanya orang yang menghidupkan bayanganya untuk menerangkan sesuatu dan terjadi karena manusia yang membuat berdasarkan hukum. Jadi merupakan orang buatan hukum atau "peson ficta". ${ }^{20}$

b. Teori kekayaan tujuan (A.Brinz dan EJJ van derHeyden).

Menurut teori ini kekayaan badan hukum itu kekayaan seseorang, tetapi kekayaan itu terikat pada tujuannya (Zweekvermogen). Tiap hak tidak ditentukan oleh suatu subyek tetapi ditentukan oleh suatu tujuan. Menurut teori ini hanya manusialah yang bisa menjadi subyek hukum dan badan hukum adalah untuk melayani kepentingan tertentu. Dalam teori A,Brinz hanya dapat nenerangkan dasr yuridis dan yayasan. ${ }^{21}$

c. Teori organ atau teori peralatan atau kenyataan (Otto von Gierke). Menurut teori ini badan hukum adalah sesuatu yang sungguh-sungguh ada didalam pergaulan yang mewujudkan kehendaknya dengan perantaraan alat-alatnya (organ)yang ada padanya (pengurusnya), jadi bukanlah sesuatu fiksi tapi merupakan makhluk yang ada sungguhsungguh secara abstrak dari kontruksi yuridis. ${ }^{22}$

d. Teori milik kolektif atau popriete Collectief (W.L.P.A.Molengraff dan marcel planiol). Dalam teori ini badan hukum ialah harta yang tidak dapat dibagi-bagi dari anggota-anggota secara bersama-sama. Hak/ kewajiban badan hukum pada hakikatnya dalam hak/kewajiban para anggota bersama-sama, oleh karenanya badan hukum hanyalah konstruksi yuridis, jadi pada hakikatnya abstak. ${ }^{23}$

e. Teori Duguit.

Sesuai dengan ajarannnya tentang fungsi sosial maka juga dalam teori ini Duguit tidak mengakui badan hukum sebagai subyek hukum tetapi

\footnotetext{
20 Ibid., 243.

21 Ibid.

22 Ibid.

${ }^{23}$ Ibid., h. 243-244.
} 
hanya fungsi-fungsi sosial yang harus dilaksanankan. Manusia sajalah sebagai subyek hukum, lain dari pada manusia tidak ada subyek hukum. $^{24}$

f. Teori Eggens.

Dalam teori ini badan hukum adalah suatu "hulpfiguur", karena adanya diperlukan dan dibolehkan hukum, demi untuk menjalankan hakhak dengan sewajarnya (behoorlijk). Bahwa dalam hal-hal tertentu keperluan itu dirasakan, oleh karena hukum hendak memperlakukannnya sesuatu romongn orang yang besama-sama mempunyai kekayaan dan tujuan tertentu sebagai suatu kesatuan, karena seseorang subyek hukum (manusia) tidak dapat (brewenag) sendiri-sendiri bertindak dalam rangkaian peristiwa-peristiwa hukum itu. ${ }^{25}$

\section{Lembaga Keuangan Syariah sebagai Badan Hukum}

\section{Definisi Lembaga Keuangan Syariah}

Lembaga keuangan (financial Institution) adalah suatu perusahaan yang usahanya bergerak dibidang jasa keuangan. Artinya kegiatan yang dilakukan oleh lembaga ini akan selalu berkaitan dengan bidang keuangan, apakah penghimpunan dana, menyalurkan dan/jasa-jasa keuangan lainnya. Dalam dunia bisnis,lembaga keuangan memiliki fungsi sangat penting, terutama sebagai lembaga intermediasi (financial intermediary) diantara para pemilik modal dengan pihak lain yang membutuhkannya. Hubungan antara semua pihak yang terkait dengan lembaga keuangan, harus dibentuk atas dasar kontrak perjanjian atau perikatan. ${ }^{26}$

Berdasarkan definisi, kriteria dan teori-teori badan hukum yang telah diuraikan di atas, maka Lembaga Keuangan Syariah merupakan badan hukum dan sekaligus subyek hukum yang wajib mengeluarkan zakat sebagai badan usaha.

\section{Bentuk-bentuk Lembaga Keuangan Syariah}

Lembaga keuangan syariah mempunyai berbagai bentuk, yaitu:

\footnotetext{
${ }^{24}$ Ibid., h. 244.

25 Ibid.

26 Burhanudin S, Hukum Bisnis..,, hal. 108.
} 


\section{a. Bank syariah}

Menurut (pasal 1 angka 2) Undang-undang perbankan syariah No.21 tahun 2008, yang dimaksud bank adalah badan usaha yang menghimpun dana dari masyarakat dalam bentuk simpanan dan menyalurkannya kepada masyarakat dalam bentuk kredit/bentuk lainnya dalam rangka meningkatkan tarif hidup rakyat. Sedangkan bank yang menjalankan kegiatan usahanya berdasarkan prinsip syariah disebut bank syariah (pasal 1 angka 7). Prinsip syariah adalah prinsip hukum islam dalam kegiatan perbankan berdasarkan fatwa yang dikeluarkan oleh lembaga yang memiliki kewenangan dalam menetapkan fatwa dibidang syariah (pasal 1 angka 12). ${ }^{27}$

\section{b. Asuransi Syariah (takaful)}

Menurut fatwa tentang pedoman umum asurasi syariah No. 21/DSNMUI/X/2001, pengertian Asuransi Syariah (ta'min,takful,tadhamun) adalah usaha saling melindungi dan tolong-menolong diantara sejumlah orang/pihak melalui investasi dalam bentuk aset dan tabarru' yang memberikan pola pengembalian untuk menghadapi resiko tertentu melalui akad(perikatan) yang sesuai dengan syariah. ${ }^{28}$

\section{c. Pasar modal syariah}

Menurut Undang-Undang pasar modal No.8 Tahun 1995, pengertian pasar modal ialah "kegiatan yang berkaitan dengan penawaran umum dan perdagangan efek yang diterbitkannya,serta lembaga dan profesi yang berkaitan dengan efek" (pasal 1 angka 13). Pasar modal adalah tempat bertemunya antara penjual dan pembeli untuk melakukan transaksi dalam rangka mendapatkan modal. Lembaga pasar modal yang menjalankan kegiatan usaha berdasarkan prinsip-prinsip syariah dapat disebut sebagai pasar modal syariah. ${ }^{29}$

\section{d. Pegadaian Syariah}

Dalam fiqh muamalah, perjanjian gadai disebut rahn. Istilah rahn secara

27 Lebih lanjut baca M. Nur Rianto Ali Arif, Lembaga Keuangan Syariah: Suatu Kajian Teoretis Praktis, (Bandung: Pustaka Setia, 2012), hal. 98.

28 Burhanudin S, Hukum Bisnis ...,hal. 135.

29 Ibid., hal. 141. 
bahasa berarti "menahan". Maksudnya adalah menahan sesuatu untuk dijadikan jaminan utang. Sedangkan gadai menurut hukum syara' adalah: Menjadikan suatu barang yang mempunyai nilai harta dalam pandangan syara' sebagai jaminan utang, yang memungkinkan untuk mengambil seluruh atau sebagian utang dari barang tersebut.

Istilah rahn memiliki akar yang kuat di dalam surat al-Mudtsir ayat 38:

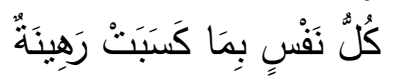

Tiap diri terikat (tergadai) dengan apa yang telah diperbuatnya.

\section{e. Lembaga pembiayaan}

Lembaga pembiayaan adalah badan usaha yang melakukan kegiatan pembiayaan dalam bentuk penyediaan dana atau barang modal dengan tidak menarik dana atau barang modal dengan tidak menarik barang secara langsung dari masyarakat. Menurut peraturan menteri keuangan No.84/ PMK.012/2006, badan usaha diluar bank dan lembaga keuangan bukan bank yang khusus didirikan untuk melakukan kegiatan yang termasuk lembaga pembiayaan disebut perusahaan pembiayaan.

\section{f. Dana pensiun}

Dana pensiun adalah sekumpulan aset yang dikelola dan dijalankan oleh suatu lembaga untuk menghasilkan manfaat pensiun, yaitu suatu pembayaran berkala yang dibayarkan kepada peserta dengan cara ditetapkan dalam ketentuan yang menjadi dasar penyelenggaraan program pensiun . pembayaran tersebut dikaitkan dengan pencapaian usia tertentu. Menurut undang-undang No. 11 tahun 1992, pengertian dana pensiun adalah badan hukum yang menjanjikan manfaat pensiun. ${ }^{30}$

\section{E. Ketentuan Zakat Lembaga Keuangan Syariah sebagai Badan Hukum}

Melihat definisi dan macam-macam Lembaga Keuangan Syariah di atas, maka sudah sangat cukup untuk dikategorikan sebagai muzakki, karena selain sebagai subyek hukum, ia juga sebagai bentuk badan hukum yang bergerak dalam bidang usaha yang profitable atau mengahsilkan dan mengembangkan modal. Pada dasarnya lembaga-lembaga keuangan syariah tersebut merupa-

\footnotetext{
30 Ibid. hal. 200.
} 
kan perusahaan yang bergerak di bidang permodalan dan jasa keuangan lainnya.

Shahaddin Zaim menjelaskan mengenai kewajiban zakat perusahaan atau badan hukum:

"The position with regard to the liability of the company issuing shares, to pay Zakah in respect of its net assets, in addition to the share holders paying Zakah in respect of shares in their hands, is, however, unclear. One view is that a company is a judicial person in its own right, distinct from the person of the shareholder, and that the payment of Zakah by him in respect of the shares he holds as a store of value, or goods for trade, does not absolve the company of its own distinct liability to pay Zakah in respect of its own net assets. The other view is that charging Zakah both from the shareholders in respect of their shares, as also from the company in respect of its net assets, may appear to amount to charging Zakah in respect of the same asset twice, within the same Zakah year, which is not permissible. This area may also need some more deliberation." $" 31$

Berkaitan dengan badan hukum sebagai muzakki, dalam hal ini UndangUndang No. 38 tahun 1999 tentang Pengelolaan Zakat dalam pasal 1 ayat (3) menyebutkan bahwa: "Muzakki adalah orang atau badan yang dimiliki oleh orang muslim yang berkewajiban menunaikan zakat. Hal ini juga disebutkan dalam Undang-Undang No. 23 tahun 2011 tentang Pengelolaan Zakat dalam pasal 1 ayat (5) yang menyebutkan bahwa: "Muzaki adalah seorang muslim atau badan usaha yang berkewajiban menunaikan zakat". Selain itu, dalam Kompilasi Hukum Ekonomi Syariah pasal 675 ayat (2) juga disebutkan bahwa: "Muzaki adalah orang atau lembaga yang dimiliki oleh muslim yang berkewajiban menunaikan zakat."

Berdasarkan pemikiran dan landasan hukum di atas, maka sudah sangat jelas bahwa badan hukum termasuk Lembaga Keuangan Syariah juga termasuk muzakki atau pihak yang mempunyai kewajiban untuk mengeluarkan zakat. Hal ini karena badan hukum juga mempunyai ahliyatul adâ' dan ahliyatul wujûb. Badan hukum yang wajib zakat adalah badan hukum yang menjalankan usaha. Setidaknya ada lima bentuk usaha yang biasa dijalankan seuatu badan hukum, yaitu:

a. Bidang industri. Misalnya pabrik radio, tv, motor, mobil, tekstil, dan lainlain.

31 I.A. Imtiazi, et. all., Management of Zakah in Modern Moslem Society, (second edition), (Karachi: Islamic Development Bank, 2000), h. 16. 
b. Bidang perdagangan. Misalnya agen, makelar, toko besar, toko kecil, dan lain-lain.

c. Bidang jasa. Misalnya konsultan, penilai, akuntan, biro perjalanan, perhotelan, dan lain-lain.

d. Bidang agraris. Misalnya pertanian, peternak, perkebunan, dan lain-lain.

e. Bidang ekstraktif. Misalnya pertambangan, penggalian, dan lain-lain. ${ }^{32}$

\section{Definisi zakat badan hukum}

Zakat secara etimologi berarti berkembang dan bertambah. Zakat juga berarti suci, sebagaimana firman Allah dalam surat al-Syams ayat 9: قد أفلح من زكاها "Sesungguhnya beruntunglah orang yang mensucikan jiwa itu", maksudnya قد أفلح من نزكى : قا "Sesungguhnya beruntunglah orang yang membersihkan diri (dengan beriman)." Zakat juga berarti pujian. Hal ini bisa sebagaimana disebutkan dalam surat al-Najm ayat 32: فلا تزكوا أنفسكم "Maka janganlah kamu mengatakan dirimu suci", maksudnya janganlah engkau memuji dirimu sendiri. ${ }^{33}$ Jadi makna zakat pada dasarnya adalah suci, berkembang, berkah dan terpuji. ${ }^{34}$

Secara etimologi zakat adalah sebutan untuk suatu yang dikeluarkan untuk mensucikan harta atau diri manusia dengan cara tertentu. ${ }^{35}$ Al-Shawi dalam kitabnya Hasyiyah al-Shâwî ‘ala al-Syarh al-Shaghîr menyatakan:

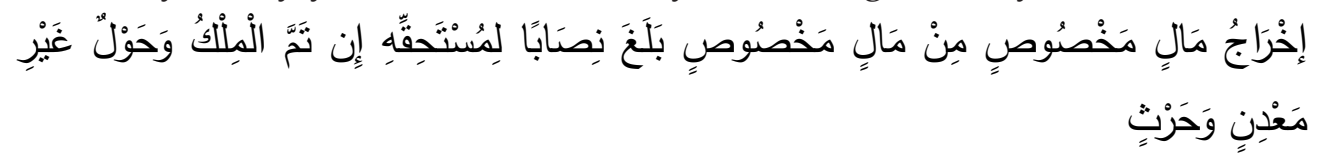

"Mengeluarkan suatu harta tertentu dari bagian harta tertentu yang telah mencapai satu nishab, apabila harta tersebut menjadi milik sepenuhnya bagi seseorang dan telah mencapai setahun selain pertanian dan barang tambang. ${ }^{36}$

32 Richard Burton Simaratumpang, Aspek Hukum Dalam Bisnis, (Jakarta: Rineka Cipta, 2007), h.1.

${ }^{33}$ Wahbah al-Zuhailî, al-Figh al-Islami wa Adillatuh, (Beirut: Darul Fikr al-Mu'ashirah, 2002), III/152.

${ }^{34}$ Ibnu Manzhur al-Afriqî al-Mishrî, Lisan al-'Arab, (Digital Library, Maktabah Syâmilah al-Ishdâr al-Tsânî, 2005), XIV/358.

35 Abu Yahya Zakaria Al-Anshari "Fathul Wahhab, (Digital Library, Maktabah Syâmilah al-Ishdâr al-Tsânî, 2005), I/179.

36 Al-Shawi, Hasyiyah al-Shâwî̀ 'ala al-Syarh al-Shaghîr, (Digital Library, Maktabah Syâmi- 
Menurut al-Qaradhawi zakat secara syara' adalah bagian tertentu dari harta yang Allah wajibkan untuk diberikan kepada para mustahiq. ${ }^{37}$ Zakat secara syara' dinamakan zakat karena dengan zakat dapat berkembang dengan berkah dan membersihkan diri seseorang dengan ampunan. ${ }^{38}$

Undang-undang No. 38 tahun 1999 tentang Pengelolaan Zakat pasal 1 ayat (2) menyebutkan bahwa: "Zakat adalah harta yang wajib disisihkan oleh seorang muslim atau badan yang dimiliki oleh orang muslim sesuai dengan ketentuan agama untuk diberikan kepada yang berhak menerimanya." Sedangkan pada undang-undang No. 23 tahun 2011 tentang pengelolaan zakat pada pasal 1 ayat (2) disebutkan bahwa "Zakat adalah harta yang wajib dikeluarkan oleh seorang muslim atau badan usaha untuk diberikan kepada yang berhak menerimanya sesuai dengan syariat Islam." sementara Kompilasi Hukum Ekonomi Syariah (KHES) tahun 2008 mendefinisikan zakat pada pasal 675 ayat (1) "Zakat adalah harta yang wajib disisihkan oleh seorang muslim atau lembaga yang dimiliki oleh muslim untuk diberikan kepada yang berhak menerimanya."

Berdasarkan pemaparan definisi zakat dia atas, jelas bahwa definisi zakat menurut undang-undang dan KHES lebih komprehensif, karena tidak hanya berkaitan dengan zakat perorangan, akan tetapi juga terkait dengan badan hukum. Artinya muzakki tidak hanya terbatas pada seseorang, akan tetapi juga badan hukum, karena badan hukum juga termasuk subyek hukum. Dengan demikian, maka zakat badan hukum adalah zakat yang wajib dikeleuarkan oleh suatu badan hukum dalam hal ini adalah Lembaga Keuangan Syariah karena bergerak dalam bidang usaha profitable.

\section{Dasar Hukum Zakat Badan Hukum}

Setidaknya ada beberapa dasar hukum yang menjadi landasan kewajiban zakat badan hukum. Ada dasar hukum dari al-Quran, al-Sunnah, undang-undang dan Peraturan Mahkamah Agung No. 2 tahun 2008 tentang Kompilasi Hukum ekonomi Syariah.

lah al-Ishdâr al-Tsânî, 2005), III/63.

37 Yusuf al-Qardhawi, Fiqh al-Zakah, (Digital Library, Maktabah Syâmilah al-Ishdâr al-Tsânî, 2005), I/47.

38 Qasim bin Abdullah bin Amîr 'Ali al-Qunuwî, Anîs al-Fuqahâ', (Digital Library, Maktabah Syâmilah al-Ishdâr al-Tsânî, 2005), I/130. 


\section{a. Dasar hukum dari al-Quran}

1) Surat al-Baqarah ayat 267 :

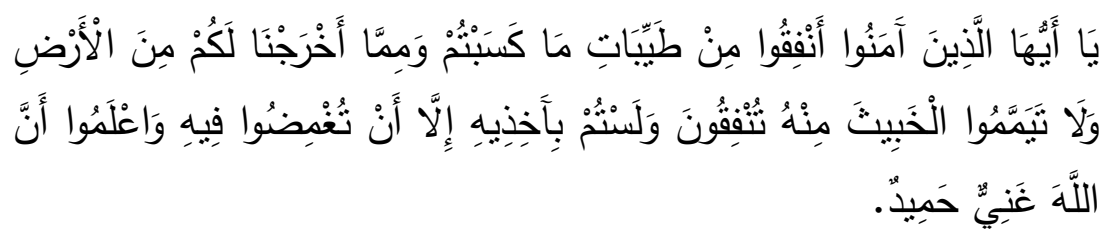

"Hai orang-orang yang beriman, nafkahkanlah (di jalan Allah) sebagian dari hasil usahamu yang baik-baik dan sebagian dari apa yang kami keluarkan dari bumi untuk kamu. dan janganlah kamu memilih yang burukburuk lalu kamu menafkahkan daripadanya, padahal kamu sendiri tidak mau mengambilnya melainkan dengan memincingkan mata terhadapnya. dan Ketahuilah, bahwa Allah Maha Kaya lagi Maha Terpuji."

2) Surat al-Taubah ayat 103:

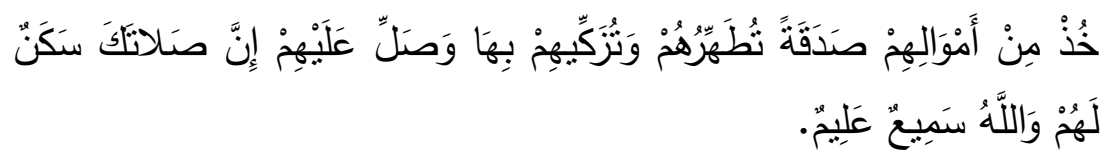

"Ambillah zakat dari sebagian harta mereka, dengan zakat itu kamu membersihkan dan mensucikan mereka dan mendoalah untuk mereka. Sesungguhnya doa kamu itu (menjadi) ketenteraman jiwa bagi mereka. dan Allah Maha mendengar lagi Maha Mengetahui."

Bila dianalisa, dalil-dalil di atas dapat dikategorikan dalil umum atau mujmal. ${ }^{39}$ Ayat 267 Surat al-Baqarah menggunakan kata أَنْفِقُو (infakkanlah) yang berarti masih umum. Infaq pada dasarnya bermakna memanfaatkan atau menasharrufkan harta. ${ }^{40}$ Meskipun mengggunakan kata I أنفْفُو, , namun menurut

39 Mujmal yaitu, suatu ungkapan yang menunjukkan sesuatu yang masih umum, tidak ada batasan dan tidak menunjukkan pada suatu secara spesifik dan tidak tertentu. Lafazh Mumal hakikatnya tidak dapat diketahui kecuali dengan qorinah atau penjelas. Dalam kitab al-Mu'tamad disebutkan:

$$
\text { المجمل هو ما أفاد شيئا من جملة أثنياء هو متعين في نفسه و اللفظ لا يعينه و لا يلزم عليه }
$$

(Abu al-Husain al-Bashrî,al-Mu'tamad fî Ushûl al-Fiqh, (Digital Library, Maktabah Syâmilah al-Ishdâr al-Tsânî, 2005), I/293. Lihat juga Anonim, Hasyiyah al-'Aththar 'ala Syrah al-Jalâl al-Mahallî 'ala Jam'i al-Jawâmi', (Digital Library, Maktabah Syâmilah al-Ishdâr al-Tsânî, 2005), VI/90.

40 Dalam hal ini Ibnu Manzhur menyatakan: 
al-Thabarî kata tersebut maksudnya perintah untuk zakat. Dalam hal ini alThabarî menyatakan:

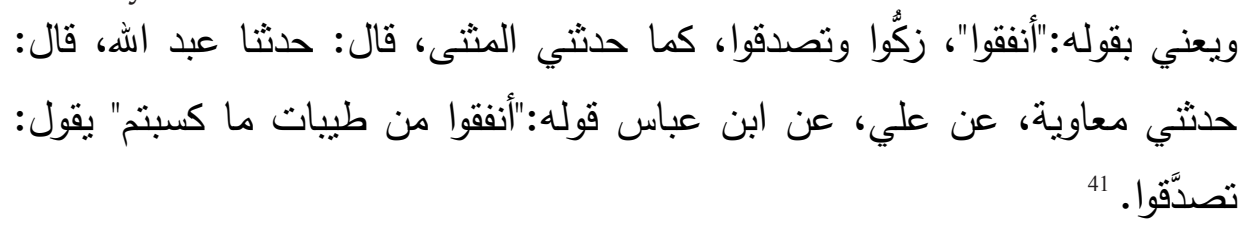

Sementara mengenai ta'wil kata "lebih lanjut alTahabari menyatakan:

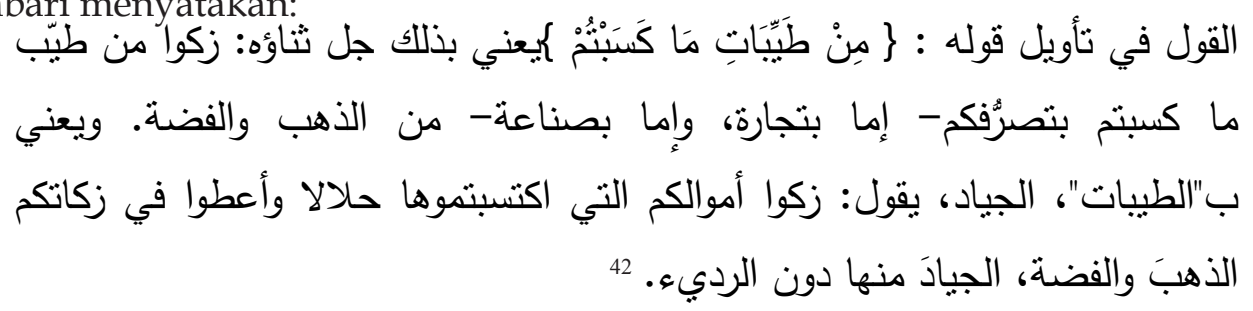

Sementara ayat kedua, menunjukkan lebih spesifik, yaitu menggunakan kata صدقةyang berarti zakat. Qorinah-nya adalah lafazh تطهر هم وتزكيهم بها. Artinya ayat ini lebih khusus, karena menunjukkan perintah untuk mengambil zakat, sementara zakat tidak dapat diambil dari setiap orang mukmin secara umum. Ada bantasan yang membuat ayat ini berarti khusus, yaitu zakat diambil dari orang mukmin yang mempunyai harta yang wajib dizakati, jumlahnya minimal satu nisab, harta tersebut dimiliki lebih dari setahun (kecuali rikaz dan pertanian), harta tersebut merupakan kelebihan dari kebutuhan pokok dan batasan-batasan lain. Namun demikian, keumuman mengenai jumlah orang yang memiliki harta masih saja berlaku, artinya, apakah harta dimiliki bersama atau milik perseorangan tetap dikenakan wajib zakat.

\section{b. Dasar hukum dari al-Sunnah}

1) Hadis riwayat Bukhari dari Anas bin Malik:

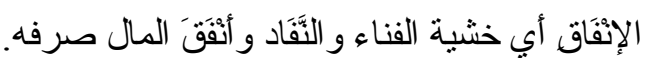

Ibnu Manzhûr al-Afriqî al-Mishrî, Lisan al-'Arab..X/357.

${ }^{41}$ Muhammad bin Jarîr bin Yazîd bin Katsir bin Ghâlib al-Amalî Abû Ja'far al-Thabarî, Jami' al-Bayân fî̀ Ta'wîl al-Quran, (Digital Library, Maktabah Syâmilah al-Ishdâr al-Tsânî, 2005), $\mathrm{V} / 555$.

42 Ibid. 


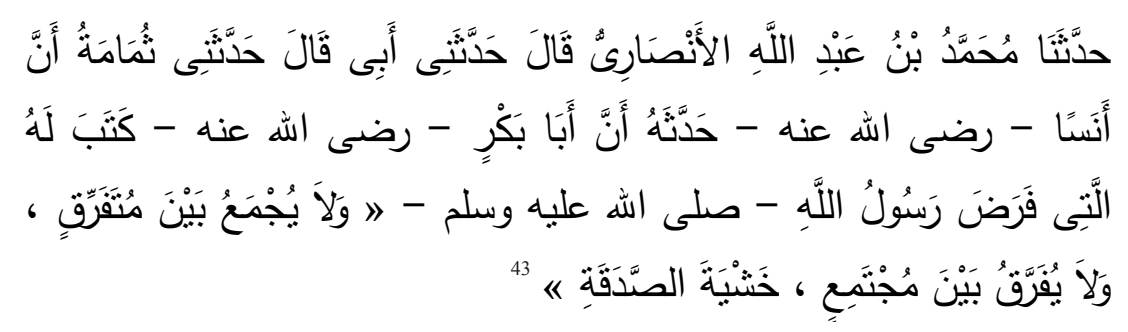

2) Hadis riwayat Bukhari dari Anas bin Malik:

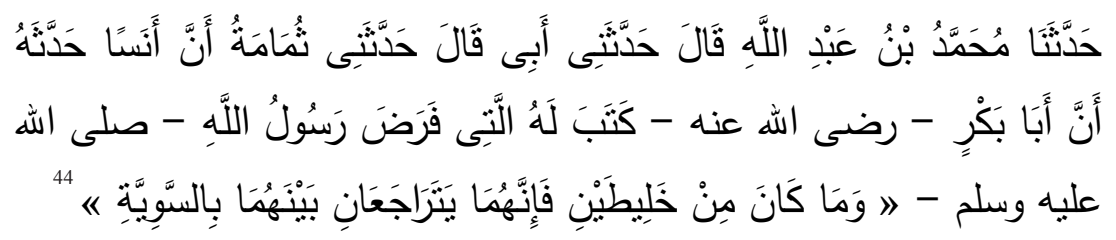

Pada dasarnya hadis-hadis di atas berkaitan tentang zakat perkongsian (syirkah) pada kepemilikan binatang ternak, namun hal ini dapat diterapkan pada zakat perkongsian kepemilikan harta kekayaan lainnya, termasuk saham badan hukum atau perusahaan. Kepemilikan harta yang profitable atau bertujuan untuk mengembangkan harta dan mencari keuntungan dari modal, wajib dizakati sebagaimana kepemilikan binatang ternak.

\section{c. Dasar hukum dari undang-undang}

1) Undang-undang No. 38 tahun 1999 tentang Pengelolaan Zakat pasal 1 ayat (2) menyebutkan bahwa: "Zakat adalah harta yang wajib

43 Muhammad bin Ismail Abu Abdullah Al-Bukharî, Shohih al-Bukhârî (Digital Library, Maktabah Syâmilah al-Ishdâr al-Tsânî, 2005), V/435, hadis No. 1450; Abu Daud, Sunan Abu Daud, (Digital Library, Maktabah Syâmilah al-Ishdâr al-Tsânî, 2005), V/97, hadis No. 1570; Al-Nasâ'̂̂, Sunan al- Nasâ'î. (Digital Library, Maktabah Syâmilah al-Ishdâr al-Tsânî, 2005), V/20, hadis No. 2446; Al-Turmudzî, Sunan al-Turmudzî. (Digital Library, Maktabah Syâmilah al-Ishdâr al-Tsânî, 2005), III/65, hadis No. 624; Ibnu Mâjah, Sunan Ibni Mâjah, (Digital Library, Maktabah Syâmilah al-Ishdâr al-Tsânî, 2005), V/463, hadis No. 1879; lihat juga Ahmad Bin Hanbal, Musnad Ahmad, (Digital Library, Maktabah Syâmilah al-Ishdâr al-Tsânî, 2005), I/76, hadis No. 73.

44 Muhammad bin Ismail Abu Abdullah Al-Bukharî, Shohih al-Bukhârî (Digital Library, Maktabah Syâmilah al-Ishdâr al-Tsânî, 2005), V/437, hadis No. 1451; Abu Daud, Sunan Abu Daud, (Digital Library, Maktabah Syâmilah al-Ishdâr al-Tsânî, 2005), V/96, hadis No. 1569; lihat juga Ahmad Bin Hanbal, Musnad Ahmad, (Digital Library, Maktabah Syâmilah al-Ishdâr al-Tsânî, 2005), X/263, hadis No. 4735. 
disisihkan oleh seorang muslim atau badan yang dimiliki oleh orang muslim sesuai dengan ketentuan agama untuk diberikan kepada yang berhak menerimanya." Dan pasal 11 ayat (2) yang menyatakan:

"Harta yang dikenai zakat adalah: a) emas, perak dan uang; b) perdagangan dan perusahaan; c) hasil pertanian, hasil perkebunan dan hasil perikanan; d) hasil pertambangan; e) hasil peternakan; f) hasil pendapatan dan jasa; g) rikaz;"

2) undang-undang No. 23 tahun 2011 tentang pengelolaan zakat pada pasal 1 ayat (2) disebutkan bahwa "Zakat adalah harta yang wajib dikeluarkan oleh seorang muslim atau badan usaha untuk diberikan kepada yang berhak menerimanya sesuai dengan syariat Islam." Pasal 4 ayat (2) menyatakan:

"Zakat mal sebagaimana dimaksud pada ayat (1) meliputi: a) emas, perak, dan logam mulia lainnya; b) uang dan surat berharga lainnya; c) perniagaan; d) pertanian, perkebunan, dan kehutanan; e) peternakan dan perikanan: f) pertambangan; g) perindustrian; h) pendapatan dan jasa; dan i) rikaz."

\section{d. Dasar hukum KHES}

Kompilasi Hukum Ekonomi Syariah (KHES) tahun 2008 mendefinisikan zakat pada pasal 675 ayat (1) "Zakat adalah harta yang wajib disisihkan oleh seorang muslim atau lembaga yang dimiliki oleh muslim untuk diberikan kepada yang berhak menerimanya."Pasal 680 menyatakan: "Zakat diwajibkan terhadap barang-barang hasil produksi apabila telah memenuhi syarat." Pasal 681 menyatakan: "Zakat dikenakan juga pada produk lembaga keuangan syari'ah, baik bank maupun non-bank, yang ketentuannya disesuaikan menurut akad masing-masing produk." Pasal 685 menyatakan: "Yang berkewajiban zakat adalah orang atau badan hukum."

\section{Syarat zakat Lembaga Keuangan Syariah sebagai badan hukum}

\section{a. Syarat Badan Hukumnya}

1) Badan hukum yang wajib zakat merupakan tempat bekerja orangorang yang beragama Islam, atau setidaknya sebagian besar yang bekerja adalah orang Islam. 
2) Badan hukum yang wajib zakat merupakan badan hukum yang menjalankan usaha yang profitable dan berkembang. Hal ini sesua dengan persyaratan zakat yang disebutkan dalam Ensiklopedi Fiqih:

النّماء: ووجه اشتراطه على ما قال ابن الهمام ، أنّ المقصود من شرعيّة الزّكاة

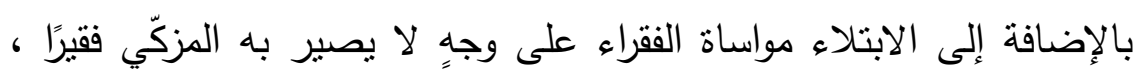
بأن يعطي من فضل ماله قليلًا من كثيرٍ ، والإيجاب في المال الّّي لا نماء

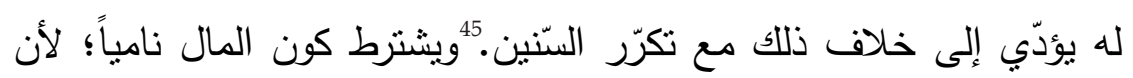

معنى الزكاة وهو النماء لا يحصل إلا من المال النامي، وليس المقصود حقيقة

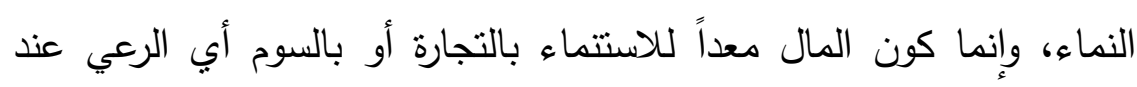

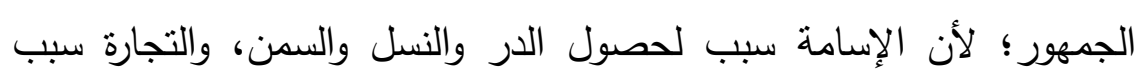

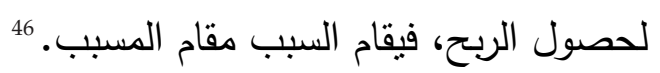

3) Usaha yang dijalankan oleh badan hukum tersebut merupakan usaha yang halal;

4) Badan hukum tersebut tidak memiliki hutang yang apabila dibayar, maka asetnya tidak sampai satu nisab. Persyaratan ni berdasarkan pendapat ulama Hanbaliyah:

الدين يمنع وجوب الزكاة في الأموال الباطنة وهي الأثمان (النقود) وعروض التجارة، لقول عثمان بن عفان: 》هذا شهر زكانكم، فمن كان عليه دين،

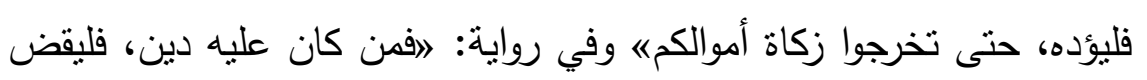
دينه، وليترك بقية مالهه قال ذلك بمحضر من الصحابة، فلم ينكروه، فدل فئل على اتفاقهم عليه.

Wahbah al-Zuhailî menambahkan bahwa apabila aset yang ada di-

${ }^{45}$ Kementerian Wakaf dan Urusan Islam Kuwait, al-Mausû'ah al-Fiqhiyah al-Kuwaitiyah, (Digital Library, Maktabah Syâmilah al-Ishdâr al-Tsânî, 2005), II/8172.

46 Wahbah al-Zuhailî, al-Figh al-Islami ..., III/163.

47 Ibid., III/171. 
gunakan untuk membayar hutang sisa harta tidak mencapai satu nisab, sementara tidak ada harta lain yang dapat digunakan untuk membayar hutang, maka tidak wajib zakat. Al-Zuhailî menyatakan:

ويمنع الدين الزكاة إذا كان يستغرق النصاب أو ينقصه، ولا يجد ما يقضيه سوى النصاب، أو ما لا يستغني عنه، مثل أن يكون عليه عشرون مثقالاً، وعليه منقال أو أكثر أو أقل مما ينقص به النصاب إذا قضاه بها، ولا يجد قضاء له من غير النصاب. فإن كان له ثناثون منقالاً وعليه عشرة، فعليه زكاة العشرين، وإن كان عليه أكثر من عشرة، فلا زكاة عليه، أبي أن مقدار الزكاة أو ينقصه، لا فئع الزكاة إذا زاد ماله عن الدين، فإن كان الدين مساوياً نصاب Sementara Imam Syafi'î dalam qoul jadîd sebagaimana dikutip alZuhailî berpendapat bahwa meskipun hutang itu besar sehingga bila harta digunakan untuk membayar maka sisanya tidak mencukupi satu nisab pemiliknya tetap wajib membayar zakat:

الدين الذي يستغرق أموال الزكاة أو ينقص المال عن النصاب لا يمنع وجوب الزكاة، فتجب الزكاة على ماللك المال؛ لأن الزكاة نتعلق بالعين، والدين يتعلق بالذمة، فلا يمنع أحدهما الآخر كالدين وأرش الجناية.

\section{b. Syarat yang berkaitan dengan harta}

Dalam Ensiklopedi Fiqih dijelaskan mengenai syarat-syarat zakat:

1) Harta dimiliki oleh pihak (perorangan atau badan hukum) yang jelas, maka tidak diwajibkan atas harta yang tidak ada pemiliknya yang jelas;

كون المال مملوكًا لمعيّن: فلا زكاة فيما ليس له ماللك معيّن.

48 Ibid.

49 Ibid., III/172. 
2) Kepemilikan sebagaimana disebut diatas merupakan kepemilikan yang mutlak.

ان يكون ملكيّة المال مطلقةً: وهذه عبارة الحنفيّة ، وعبّر غيرهم بالملك التّامّ: وهو ما كان في يد مالكه ينتفع به ويتصرّف فيه.

3) Harta tersebut merupakan kelebihan dari kebutuhan pokok. Syarat ini merupakan persyaratan yang dikemukakan oleh ulama Hanafiyah. Berdasarkan hal ini, para ulama mengatakan, 'Tidak ada zakat untuk kitab referensi yang digunakan oleh pemiliknya atau bukan pemiliknya, meskipun nilainya melebihi satu nishab. Demikian pula, tidak ada zakat untuk rumah yang ditinggali, perabot rumah, hewan tunggangan, dan semacamnya.

الزّيادة على الحاجات الأصليّة: وهذا الثُرط يذكره الحنفيّة. وبناءً عليه قالوا: لا زكاة في كتب العلم المقتتاة لأهلها وغير أهلها ولو كانت تساوي نصبًا، وكذا دار السّكنى وأثناث المنزل ودوابّ الرّكوب ونحو ذلك.

4) Harta tersebut berada dalam kepemilikan badan usaha telah berlangsung selama satu tahun qomariyah atau tahun hijriyah.

الحول: المراد بالحول أن يتمّ على المال بيد صاحبه سنةً كاملةً قمريّةً ، فإن

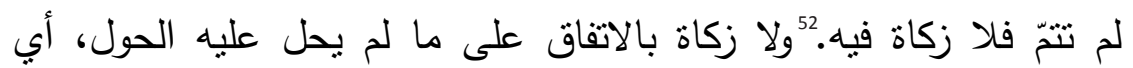
يمضي عليه سنة.

Hal ini berdasarkan hadis riwayat Aisyah:

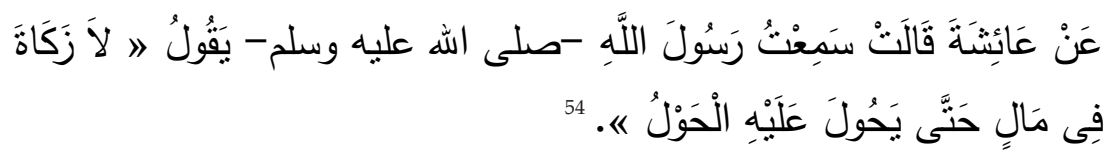

50 Ibid., II/8173.

51 Ibid.

52 Ibid., II/8173.

53 Wahbah al-Zuhailî, al-Figh al-Islami .., III/160.

54 Ibnu Mâjah, Sunan Ibni Mâjah, (Digital Library, Maktabah Syâmilah al-Ishdâr al-Tsânî, 
5) Harta tersebut harus mencapai satu nisab;

\section{Nisab dan haul zakat badan hukum}

Berkaitan dengan nishab zakat badan hukum atau perusahaan, Yusuf Qardhawi menyatakan:

فإذا أردنا أن نأخذ بهذا الاتجاهوهو النظر إلى الأسهم تبعا لنوع الشركة التجارية

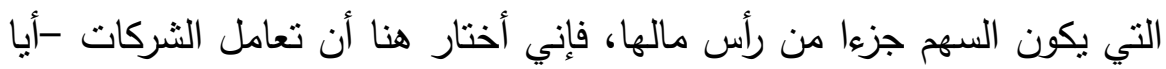

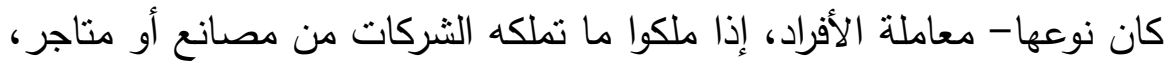

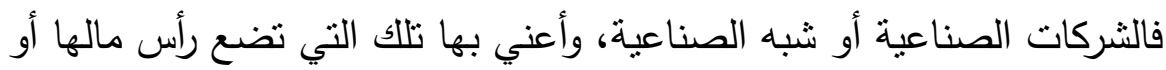
جله في أجهزة وآلات ومبان وأدوات، كالمطابع والمصانع، والفنادق، وسيارات النقل والأجرة ونحوها، هذه الشركات لا تؤخذ الزكاة من أسهمها بل من إيرادها وربحها الصافي بمقدار العشر كما رجحناه في زكاة المستغلات، وكما نعامل

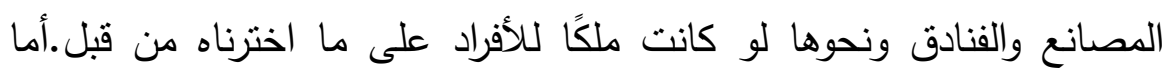
الثركات التجارية وهي التي جل رأس مالها في منقولات تتاجر فيها ولا تبقى عينها، فهذه نؤخذ الزكاة بمقدار ربع العثر (.0.0 في المائة ) بعد طرح قيمة

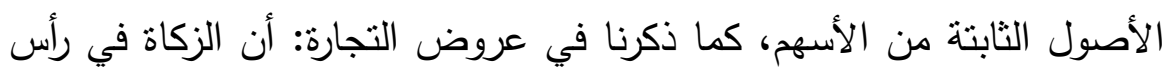
المال المتداول المتحرك، وهذه المعاملة للشركات التجارية هي نفس المعاملة التي تعامل بها المحلات التجارية إذا كانت ملكًا للأفراد ولا فرق. 55

Menurut pemikiran Yusuf Qardhawi, jika diambil dari pendapat yang melihat saham sesuai dengan jenis perusahaan dagangnya, di mana saham merupakan bagian dari modal perusahaan, maka ia lebih cenderung menyamakan perusahaan-perusahaan itu (apa pun jenisnya) layaknya individu-individu. Perusahaan-perusahaan industri atau semi industri yang dimaksudkan adalah perusahaan-perusahaan yang modalnya terletak dalam perlengkapan, alat-alat, gedung-gedung, dan perabot, se-

2005), V/440, hadis No. 1864; lihat juga Abu Bakar Ahmad bin al-Husain bin Ali al-Baihaqî, Sunan al-Baihaqî, (Digital Library, Maktabah Syâmilah al-Ishdâr al-Tsânî, 2005), II/56, hadis No. 7524.

55 Yusuf al-Qardhawi, Figh al-Zakah, (Digital Library, Maktabah Syâmilah al-Ishdâr al-Tsân̂े, 2005), I/456. 
perti percetakan, pabrik, hotel, kendaraan angkutan, taksi dan lain-lain zakatnya tidak diambil dari saham-sahamnya, namun diambil dari keuntungan bersihnya sebesar $10 \%$. Sedangkan perusahaan perdagangan, yaitu perusahaan yang kebanyakan modalnya terletak dalam bentuk barang yang diperjual-belikan dan materinya tidak tetap, maka zakatnya diambil dari sahamnya, sesuai dengan harga yang berlaku di pasar, ditambah dengan keuntungannya. Oleh karena itu, zakatnya sekitar 2.5 $\%$, setelah nilai peralatan yang masuk dalam saham, dikeluarkan. Hal ini sesuai dengan pendapat beliau mengenai harta perdagangan yaitu, bahwa zakatnya wajib atas modal yang bergerak. Perlakuan terhadap perusahaan-perusahaan dagang ini sama dengan perlakuan terhadap toko-toko dagang yang dimiliki perorangan. ${ }^{56}$

Yusuf Qaradhâwî berpendapat bahwa nisab zakat profesi atau perusahaan yang profitable adalah senilai dengan 85 gram emas. Sementara ukuran zakatnya adalah 2,5 \%. Sementara Syaikh Muhammad bin Shalih al-`Utsaimin ketika menjawab mengenai zakat perusahaan beliau menyatakan:

“..... berusahaan-persahaan yang bergerak dalamindustri perdagangan wajib padanya zakat perdagangan. Dan tidak wajib pada alat-alat, perangkat keras, mobil, bangunan, peralatan yang ingin digunakan dan tidak ingin dijual untuk mengambil keuntungan. Atas dasar ini, maka cara menghitung zakat di akhir tahun adalah bahwa dihitung apa yang ada dalam simpanan perusahaan yang telah dibeli dan bertujuan untuk dijual... semua itu ditambah uang tunai yanga da di perusahaan atau yang engkau simpan di bank. Ditambah lagi dengan piutang yang ada di tangan manusia yang engkau harapkan bisa ditagih. Kemudian engkau keluarkan zakatnya sebanyak 2,5 \%." ${ }^{57}$

Berkaitan dengan nisab zakat badan hukum sebagaimana disebutkan dalam pasal 685 KHES 2008, dijelaskan pada pasal berikutnya, yaitu pasal 686 yang menyatakan:

(1) Zakat dihitung dari seluruh penghasilan yang didapatkan kemudian dikurangi oleh biaya kebutuhan hidup.

${ }^{56}$ Diterjemahkan oleh Ririn Fauziyah dalam, Pemikiran Yusuf Qardhawi mengenai Zakat Saham dan Obligasi, dalam Jurisdictie, Jurnal Hukum dan Syariah, (Malang: Unit penelitian, penerbitan dan pengabdian Masyarakat (P3M) Fakultas Syariah Universitas Islam Negeri Maulana Malik Ibrahim ), Vol. 2, No. Juni 2011, hal. 166.

57 Syaikh Muhammad bin Shâlih al-`Utsaimin, Fatwa tentang Zakat Perusahaan, alih bahasa Muhammad Iqbal Ghazali, (islamhouse.com, 2009), hal. 4. 
(2) Besarnya nishab sama dengan besarnya nishab pada zakat barang yang memiliki nilai ekonomis, yaitu 85 gram emas.

Mengenai ukurannya, dinisbahkan pada zakat perdagangan, yaitu 2,5\%. Subyek hukum karena memiliki ahliyatul Ada' dan ahliyatul wujub.

\section{F. Penutup}

Melihat definisi dan macam-macam dan bentuk Lembaga Keuangan Syariah di atas, maka Lembaga Keuangan Syariah harus dizakati. Kewajiban zakat bagi LKS ini karena ia sebagai subyek hukum dan sekaligus sebagai badan usaha yang profitable.

Mengenai ketentuan zakat LKS, maka berlaku ketentuan yang berlaku pada badan hukum lainnya. Jadi syarat, nisab, haul dan ukuran zakat Lembaga Keuangan Syariah mengikuti ketentuan yang berlaku pada badan hukum sebagaimana yang telah dijelaskan di atas.

\section{DAFTAR PUSTAKA}

Abu al-Husain al-Bashrî,al-Mu'tamad fî Ushûl al-Figh, (Digital Library, Maktabah Syâmilah al-Ishdâr al-Tsânî, 2005)

Abu Bakar Ahmad bin al-Husain bin Ali al-Baihaqî, Sunan al-Baihaqî, (Digital Library, Maktabah Syâmilah al-Ishdâr al-Tsânî, 2005)

Abu Daud, Sunan Abu Daud, (Digital Library, Maktabah Syâmilah al-Ishdâr alTsânî, 2005).

Abu Yahya Zakaria Al-Anshari "Fathul Wahhab, (Digital Library, Maktabah Syâmilah al-Ishdâr al-Tsânî, 2005)

Ahmad Bin Hanbal, Musnad Ahmad, (Digital Library, Maktabah Syâmilah al-Ishdâr al-Tsânî, 2005).

Al-Shawi, Hasyiyah al-Shâwî̀ 'ala al-Syarh al-Shaghîr, (Digital Library, Maktabah Syâmilah al-Ishdâr al-Tsânî, 2005)

Anonim, Hasyiyah al-'Aththar 'ala Syrah al-Jalâl al-Mahallî 'ala Jam'i al-Jawâmi', (Digital Library, Maktabah Syâmilah al-Ishdâr al-Tsânî, 2005)

Bambang Purwoko, Memahami Bentuk Badan Hukum Badan Penyelenggara Jaminan Sosial (BPJS) sebagaimana mestinya, makalah hasil penelitian , penelitian tentang kesesuaian bentuk bentuk badan hukum BPJS sebagaimana mestinya sesuai asas dan prinsip UU SJSN, tahun 2010. 
Burhanudin S, Hukum Bisnis Syariah, Yogyakarta: UII Press, 2011.

Habib Ahmed, Role of Zakah and Afqaf in Poverty Alleviation, Jeddah: Islamic Develovment Bank, 2004.

Hans Kelsen, Teori Hukum Murni, (Bandung: Nusa Media, 2011), 190.

I.A. Imtiazi, et. all., Management of Zakah in Modern Moslem Society, (second edition), Karachi: Islamic Development Bank, 2000.

Ibnu Mâjah, Sunan Ibni Mâjah, (Digital Library, Maktabah Syâmilah al-Ishdâr alTsânî, 2005).

Ibnu Manzhûr al-Afriqî al-Mishrî, Lisan al-'Arab, (Digital Library, Maktabah Syâmilah al-Ishdâr al-Tsânî, 2005).

Imam Muslim, Shohih Muslim, (Digital Library, Maktabah Syâmilah al-Ishdâr alTsânî, 2005)

Kementerian Wakaf dan Urusan Islam Kuwait, al-Mausĥ'ah al-Fiqhiyah al-Kuwaitiyah, (Digital Library, Maktabah Syâmilah al-Ishdâr al-Tsân̂, 2005).

M. Nur Rianto Ali Arif, Lembaga Keuangan Syariah: Suatu Kajian Teoretis Praktis, Bandung: Pustaka Setia, 2012.

Muhammad bin Ismail Abu Abdullah Al-Bukharî, Shohih al-Bukhârî (Digital Library, Maktabah Syâmilah al-Ishdâr al-Tsânî, 2005).

Muhammad bin Jarîr bin Yazîd bin Katsir bin Ghâlib al-Amalî Abû Ja'far alThabarî, Jami' al-Bayân fî Ta'wîl al-Quran, (Digital Library, Maktabah Syâmilah al-Ishdâr al-Tsânî, 2005)

Al-Nasâ'î, Sunan al- Nasâ'î. (Digital Library, Maktabah Syâmilah al-Ishdâr al-Tsânî, 2005).

P.N.H. Simanjuntak, Pokok-Pokok Hukum Perdata Indonesia, Jakarta: Djambatan, 2009.

Qasim bin Abdullah bin Amîr 'Ali al-Qunuwî, Anîs al-Fuqahâ', (Digital Library, Maktabah Syâmilah al-Ishdâr al-Tsânî, 2005)

R. Soeroso, Pengantar Ilmu Hukum, Jakarta: PT. Sinar Grafik, 1993.

Richard Burton Simaratumpang, Aspek Hukum Dalam Bisnis, Jakarta: Rineka Cipta, 2007.

Ririn Fauziyah dalam, Pemikiran Yusuf Qardhawi mengenai Zakat Saham dan Obligasi, dalam Jurisdictie, Jurnal Hukum dan Syariah, (Malang: Unit penelitian, penerbitan dan pengabdian Masyarakat (P3M) Fakultas Syariah Universitas Islam Negeri Maulana Malik Ibrahim ), Vol. 2, No. Juni 2011. 
Syaikh Muhammad bin Shâlih al-'Utsaimin, Fatwa tentang Zakat Perusahaan, alih bahasa Muhammad Iqbal Ghazali, islamhouse.com, 2009.

Al-Turmudzî, Sunan al-Turmudzî. (Digital Library, Maktabah Syâmilah al-Ishdâr al-Tsân̂े, 2005).

Undang-undang No. 23 tahun 2011 tentang Pengelolaan Zakat

Undang-undang No. 38 Tahun 1999 tentang Pengelolaan Zakat

Wahbahal-Zuhailî, al-Fiqhal-Islami wa Adillatuh, Beirut: DarulFikral-Mu'ashirah, 2002.

Yusuf al-Qardhawi, Figh al-Zakah, (Digital Library, Maktabah Syâmilah al-Ishdâr al-Tsânî, 2005).

------, Figh al-Zakah, Beirut: Muassasah Risalah, 1973. 
